\title{
Brátt hjartadrep á Íslandi í fertugum og yngri 2005-2009
}

Samanburður við tímabilið 1980-1984

\author{
Björn Jakob Magnússon' læknir, Uggi Agnarsson² læknir, Pórarinn Guð̋nason² læknir, \\ Guð̋mundur Porgeirsson ${ }^{1,2}$ læknir
}

\section{Á G R I P}

Inngangur: Pótt brátt hjartadrep sé fyrst og fremst sjúkdómur eldra fólks getur pað valdið ótímabærum dauða, heilsubresti og skertum lífsgæðum hjá yngra fólki. Árin 1980-1984 voru nýgengi, áhættupættir, staðsetning hjartadreps, ástand kransæða og afdrif eftir hjartadrep meðal fertugra og yngri könnuð á Íslandi. Í pessari rannsókn voru sambærileg atriði skoðuð fyrir tímabilið 2005-2009 og borin saman við fyrri rannsóknina. Efniviður og aðferðir: Kannaðar voru sjúkraskrár fertugra og yngri sem á árunum 2005-2009 fengu greininguna brátt hjartadrep (121 samkvæmt ICD-10) á Landspítalanum. Einnig var farið yfir krufningaskýrslur peirra sem dóu skyndidauða og fengu greininguna brátt hjartadrep. Loks voru niðurstöður blóðrannsókna, hjartarafrita, hjartaómskoðana, hjartapræðinga og krufninga metnar með tilliti til greiningarskilmerkja fyrir hjartadrep. Kí-kvaðrat próf var notað við samanburð hlutfalla en t-prófun við samanburð meðaltala.

Niðurstöður: Alls uppfylltu 38 einstaklingar 40 ára eða yngri greiningarskilmerki fyrir brátt hjartadrep, 32 karlar og 6 konur. Nýgengi var 10/100.000/ári (14/100.000/ári 1980-1984) og meðalaldur \pm SF var 36,7 ár \pm 3 ,9. Prír (7,9\%) dóu skyndilega og komust aldrei á sjúkrahús. Af 35 inn- lögðum sjúklingum árin 2005-2009 dó enginn innan 30 daga frá áfallinu. Tímabilið 1980-84 létust 9 (23,7\%) áđur en peir komust á sjúkrahús en 2 á sjúkrahúsi. Heildardánartíðni var bví 28,9\% tímabilið 1980-1984 en 7,9\% tímabilið 2005-2009 ( $p=0,02)$. Meðal innlagðra höfðu 77,1\% reykingasögu en $97 \%$ á fyrra tímabilinu $(p=0,026)$. Hins vegar var hlutfall háprýstingssjúklinga hærra á síðara tímabilinu, 31,4\% samanborið við 6,9\% $(p=0,015)$ og einnig líkamspyngdarstuðull, $28,6 \pm 4,8 \mathrm{~kg} / \mathrm{m}^{2}$ á seinna tímabili en 26, $\pm 3,6 \mathrm{~kg} / \mathrm{m}^{2}$ á pví fyrra (meðaltal $\pm \mathrm{SF} ; \mathrm{p}<0,05$ ). Meðalgildi S-kólesteróls í karlmönnum var lægra á seinna tímabilinu, 5,1 $\pm 1,4 \mathrm{mmol} / \mathrm{L} \pm \mathrm{SF}$, en 6,3 $\pm 1,2 \mathrm{mmol} / \mathrm{L} \pm \mathrm{SF}$ á pví fyrra $(\mathrm{p}<0,01)$. Líkt og 1980-84 var einnar æðar sjúkdómur algengasta útbreiðsluformið og prengsli algengust í vinstri framveggskvísl.

Ályktanir: Okkar gögn benda til að brátt hjartadrep meðal fertugra og yngri sé aðallega sjúkdómur karlmanna. Algengustu áhættupættir eru reykingar og ættarsaga. Í samanburði við fyrri rannsókn 1980-1984 eru reykingar pó minna afgerandi en pá, en háprýstingur og aukin líkamspyngd gegna stærra hlutverki. Samanlögð dánartíðni fyrir innlögn og á sjúkrahúsi lækkaði marktækt á milli rannsóknartímabila.

\section{Inngangur}

Brátt hjartadrep er alvarlegasta afleiðing kransæðasjúkdóms og ein af algengustu dánarorsökum víðast hvar í heiminum. ${ }^{1}$ Pótt ýmsar orsakir geti legið að baki blóðrásarhindrunum í kransæðum, til dæmis ytri áverkar, blóðsegarek, meðfæddir gallar í kransæðum, brád æðabólga og flysjun, er pó æðakölkun (atherosclerosis) og blóðsegamyndun í tengslum við hana langalgengasta orsökin. ${ }^{2}$ Brátt hjartadrep er fyrst og fremst algengur sjúkdómur meðal eldri einstaklinga en leggst pó einnig á ungt fólk með alvarlegum afleiðingum. Í faraldsfræðilegum rannsóknum á hjartadrepi í yngri aldurshópum hafa aldursmörkin ýmist verið dregin við 35, 40 eða 45 ára aldurinn og hlutfall ungra sjúklinga af heildarfjölda kransæðastíflutilfella hefur legið á bilinu 4-10\%. ${ }^{3-5}$

Fyrir rúmum aldarfjórðungi birtust í Læknablaðinu niðurstöður rannsóknar á faraldsfræði hjartadreps meðal 40 ára og yngri á Íslandi á árabilinu 1980-1984. ${ }^{6}$ Á pessu 5 ára tímabili reyndist nýgengi sjúkdómsins í pessum aldursflokki vera 14/100.000/ári og

'Læknadeild Háskóla Íslands, ²hjartadeild Landspítala.

Fyrirspurnum svarar Guðmundur Porgeirsson gudmth@landspitali.is

Höfundar hafa útfyllt eyðublað um hagsmunatengsı.
6,1\% dauðsfalla á pessum aldri orsakaðist af bráðu hjartadrepi. Eins og í mörgum öðrum rannsóknum voru langflestir pessara ungu sjúklinga karlmenn, nær allir stórreykingamenn frá unga aldri, og jákvæð ættarsaga um kransæðasjúkdóm var algeng. Pótt yfirleitt væri um fullpykktardrep að ræða (drep með ST-hækkun, STEMI) var kransæðasjúkdómurinn sjaldnast útbreiddur og oftast bundinn við eina kransæðagrein samkvæmt kransæðamyndatöku. ${ }^{6}$

Aldursstaðlað nýgengi og dánartíðni úr kransæðasjúkdómi hefur lækkað mjög á Íslandi eins og á öðrum Vesturlöndum frá pví fyrri rannsóknin var gerð. ${ }^{7}$ Pað er pví tímabært að kanna á ný stöðu mála í yngsta sjúklingahópnum sem í fyrri rannsókninni reyndist hafa margs konar sérstöðu miðað við aðra aldurshópa ${ }^{6}$ en pó ápekka pví sem lýst hefur verið í mörgum erlendum rannsóknum. . $^{3-5,8-14}$

Markmið pessarar rannsóknar var pví að kanna hver próunin hefur orðið meðal ungra polenda alvarlegs kransæðasjúkdóms og áherslan, eins og í fyrri rannsókninni, á nýgengi, áhættupætti og afdrif, sem og á útbreiðslu kransæðaprenginganna.

\section{Efniviður og aðferðir}

Rannsóknin var afturskyggn. Í Sögukerfi Landspítalans voru kannaðar sjúkraskrár allra sjúklinga, 40 ára og yngri, sem lögð- 
Tafla I. Samanburður á faraldsfræðilegum upplýsingum og áhættupáttum milli tímabila. \% (n).

\begin{tabular}{lccc}
\hline & $1980-1984$ & $2005-2009$ & P gildi \\
\hline Sjúklingafjöldi & $(38)$ & $(38)$ & \\
\hline Meðalaldur (bil) & ER $(25-40)$ & $\pm 3,9(24-40) 36,7$ ár & \\
\hline Hlutfall kvenna & $5,3(2 / 38)$ & $15,8(6 / 38)$ & EM \\
\hline $\begin{array}{l}\text { Hlutfall innlagna } \\
\text { vegna hjartadreps }\end{array}$ & ER & $1,7(35 / 2115)$ & \\
\hline Hlutfall látinna & $28,9(11 / 38)$ & $7,9(3 / 38)$ & 0,02 \\
\hline Præðingar & 75,9 & 94,3 & $<0,05$ \\
\hline Reykingasaga & $97(29)$ & $77,1(35)$ & 0,03 \\
\hline ÆEttarsaga & $51,7(29)$ & $62,9(35)$ & EM \\
\hline Háprýstingur & $6,9(29)$ & $31,4(35)$ & 0,01 \\
\hline Sykursýki & $3,4(29)$ & $8,635)$ & $\mathrm{NS}$ \\
\hline $\begin{array}{l}\text { S-kólesteról } \\
\text { (mmól/L) }\end{array}$ & $6,32 \pm 1,16(20)$ & $5,1 \pm 1,43(22)$ & $<0,01$ \\
\hline LPS (kg/m²) & $26,1 \pm 3,6(19)$ & $28,6 \pm 4,8(21)$ & 0,04 \\
\hline
\end{tabular}

LPS: Líkamspyngdarstuðull. ER: Ekki reiknað. EM: Ekki marktækt.

ust inn á Landspítalann á árunum 2005-9 og greindust með brátt hjartadrep og fengu við útskrift greiningarnúmerin I21 ásamt undirflokkum í ICD-10 kerfinu. Greiningarnúmerin tilgreina fullpykktar (pverdrægt) hjartadrep ásamt staðsetningum (I21.0, I21.1, I21.2, I21.3) og samsvara hjartadrepi sem veldur ST-hækkun á hjartarafriti (ST-elevation myocardial infarct, STEMI) sem og neðanpels hjartadrep (I21.4) sem ekki veldur ST-hækkun (non ST-elevation myocardial infarct, NSTEMI). Greiningarskilmerkið I21.9 er notað pegar engin staðsetning er tilgreind. Leitað var staðfestingar á eftirtöldum greiningarskilmerkjum: Brjóstverk, hjartarafritsbreytingum sem samrýmast bráðu hjartadrepi og hækkun á trópónín T (TnT). Lágmarksskilmerki hjartadreps voru: blóðpurrðarbreytingar á hjartarafriti (ST-hækkun, ST-lækkun, T-breytingar eða óeðlileg q-bylgja) og TNT-hækkun (gildi ofan skilgreindra marka Rannsóknarstofu Landspítala á hverjum tíma í að minnsta kosti einu blóðsýni, og merki um hækkun eða lækkun á gildum innan nokkurra klukkustunda). Einnig var sömu greininga leitað í krufningaskrám peirra sem létust skyndidauða utan sjúkrahúss, pað er fengu greiningarnúmerin I46 (hjartastopp) eða R96 (lést innan 24 klukkkustunda frá upphafi einkenna) og/eða fengu greiningarnúmer hjartadreps eftir krufningu og smásjárgreiningu meinafræðings. Dánartíðni á sjúkrahúsi miðaðist við 30 daga eftir að áfallið átti sér stað.

Við útreikninga á nýgengi hjartadreps var stuðst við mannfjöldatölur frá Hagstofu Íslands fyrir hvert ár. ${ }^{15}$ Auk pess voru upplýsingar um nýgengi í aldurshópnum 25-74 ára fyrir tímabilin 1980-84 og 2000-2004 fengnar úr gögnum Hjartaverndar. ${ }^{7}$

Til reykingamanna töldust peir sem sögðust einhvern tíma hafa reykt. Sjúklingar sem áttu foreldra eða systkini með sögu um kransæðasjúkdóm töldust hafa jákvæða ættarsögu en einnig pegar pess var getið í sjúkraskrá að viðkomandi hefði ættarsögu um kransæðasjúkdóm. Upplýsingar um S-kólesteról fengust úr niðurstöðum blóðrannsókna í Sögukerfi Landspítalans. Sjúk-

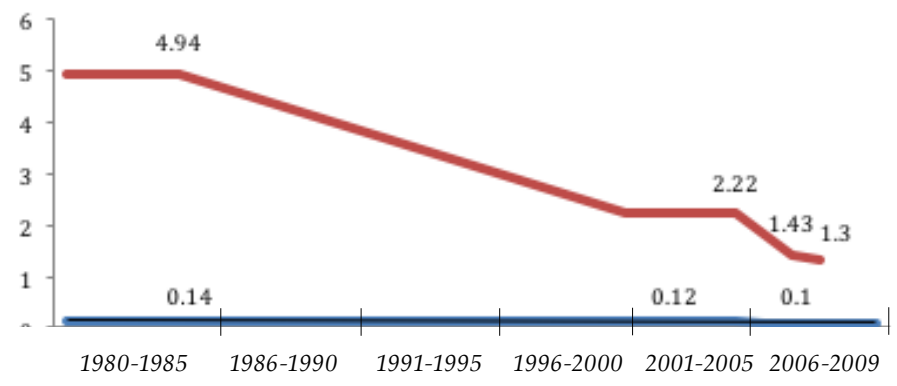

Mynd 1 Nýgengi bráđs hjartadreps á 1000 einstaklinga á ári. Aldurshópurinn 25-74 ára er rauður en 25-40 ára er blár. P gildi ( $p$ for trend) $<0,001$.

lingur taldist hafa háprýsting ef blóðprýstingur mældist tvívegis hærri en 140/90 mmHG í legunni, hann tók háprýstingslyf eða var sagður hafa háprýsting í sjúkraskýrslu. Sykursýki var skilgreind ef fyrir lá sykursýkisgreining skráð í sjúkraskrá eða blóðsykur við komu á sjúkrahúsið mældist hærri en 9,7 mmól/L. Upplýsingar um líkamspyngdarstuðul (LPS) og niðurstöður kransæðapræðinga fengust úr sjúkraskrá. Staðsetning hjartadreps var metin út frá hjartarafritsbreytingum peirra sjúklinga sem greindust með hjartadrep með ST-hækkun (STEMI). Sjúklingur var talinn hafa sögu um vímuefnanotkun ef pess var getið í sjúkraskrá.

Notast var við Microsoft Excel við úrvinnslu gagna. Við samanburð hlutfalla var notað Kí-kvaðrat próf. Við samanburð meðalgilda fyrir kólesteról og pyngdarstuðul milli tímabila var notuð t-prófun. Er pá gert ráð fyrir t-dreifingu, pað er samfelldri líkindadreifingu sem líkist normaldreifingu, er bjöllulaga og samhverf um meðaltal dreifingarinnar. Marktektarkrafan miðaðist við 5\%.

Leyfi fyrir rannsókninni fengust hjá Vísindasiðanefnd Landspítalans (10/12 2010), Persónuvernd (8/12 2010) og hjá framkvæmdastjóra lækninga á Landspítala (17/11 2010).

\section{Niðurstöður}

Árin 2005-2009 uppfylltu 38 sjúklingar (32 karlar og 6 konur) fertugir og yngri greiningarskilmerki fyrir brátt hjartadrep, ápekkur fjöldi og í rannsókninni 1980-1984, og 35 lögðust inn á sjúkrahús. Eins og fram kemur í töflu eru pað 1,7\% (35/2115) af heildarfjölda innlagðra sjúklinga með brátt hjartadrep á tímabilinu. Af spítalavistuðum sjúklingum létust tveir (6,9\%) á fyrra tímabilinu en enginn á pví síðara. Heildarfjöldi látinna innan og utan sjúkrahúsa var mun meiri á fyrra tímabilinu, 11 af 38 (28,9\%) en 3 af 38 (7,9\%) á síðara tímabilinu og er munurinn tölfræðilega marktækur $(\mathrm{p}=0,02$, tafla I).

Eins og fram kemur í töflu I reyndust 77\% af innlögðum sjúklingum hafa reykingasögu en $97 \%$ á fyrra tímabilinu og er munurinn tölfræðilega marktækur $(\mathrm{p}=0,026)$. Hins vegar var hlutfall sjúklinga með háprýsting hærra á seinna tímabilinu, 31,4\% á móti 6,9\% $(\mathrm{p}=0,015)$. LPS karlmanna var að meðaltali hærri á seinna tímabilinu $(\mathrm{p}=0,04)$ en meðalgildi kólesteróls í sermi var hins vegar lægra $(<0,01)$. Fimmtungur hafði sögu um misnotkun vímuefna 2005-09 en upplýsingar lágu ekki fyrir um fyrra tímabilið.

Eins og fram kemur á mynd 1 hefur nýgengi bráðs hjartadreps haldist nær óbreytt í aldurshópnum 40 ára og yngri, (14/100.000/ ári á fyrra tímabili en 10/100.000/ári á pví síðara) gagnstætt pví 


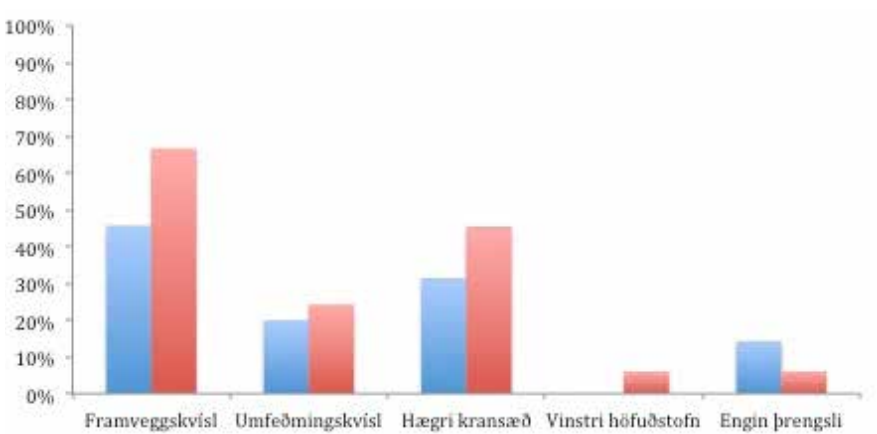

Mynd 2 Staðsetning marktækra kransæðaprengsla ( $>50 \%$ pvermálsprengsli) borin saman milli tímabila. Tímabilið 2005-9 er blátt en 1980-84 er rautt.

sem gerst hefur á aldursbilinu 25-74 ára par sem orðið hefur mikil lækkun. ${ }^{7}$

Einnar æðar sjúkdómur, pað er pvermálsprengsli $>50 \%$ greinanleg í aðeins einni kransæðargrein, var algengasta útbreiðsluformið bæði tímabilin, 59,1\% á fyrra tímabilinu og 74,1\% á pví síðara. Engin marktæk prengsli, pað er prengsli meiri en 50\% af pvermáli, fundust í 14,3\% tilfella á síðara tímabilinu en í 6,1\% tilfella á fyrra tímabilinu. Algengasta staðsetning prengsla var í vinstri framveggskvísl og átti pað við um bæði tímabilin (mynd 2). Samkvæmt hjartarafriti var framveggsdrep einnig algengasta staðsetning dreps.

\section{Umræða}

Pótt brátt hjartadrep sé sjaldgæfur sjúkdómur meðal fertugra og yngri er pað mikilvæg orsök heilsubrests og dauða. Pær miklu breytingar sem orðið hafa í nýgengi kransæðasjúkdóms síðustu áratugi í öllum aldurshópum til 74 ára aldurs, og tengsl lækkaðrar dánartíðni við breytingar í áhættupáttum, undirstrika tækifærin sem við blasa í lýðgrundaðri forvarnarstarfsemi. ${ }^{7}$ Upplýsingar um próun mála hjá yngri aldursflokkum eru pví áhugaverðar.

Mikilvægustu niðurstöður peirrar rannsóknar sem hér er kynnt eru að hjartadrep meðal fertugra og yngri er enn sem fyrr sjaldgæfur sjúkdómur pótt nýgengið hafi ekki lækkað milli tímabila eins og gerst hefur í eldri aldursflokkum. Eins og á árabilinu 19801984 eru pað fyrst og fremst karlmenn sem fá hjartadrep í pessum aldurshópi og reykingar vega enn pyngst áhættupátta pótt vægi háprýstings virðist hafa aukist milli tímabila. Loks kom fram svipað eða jafnvel enn skýrara mynstur á útbreiðslu kransæðasjúkdómsins og á fyrra tímabili, pað er hátt hlutfall sjúklinga með prengsli í aðeins einni kransæðagrein og hærra hlutfall sjúklinga par sem engin marktæk prengsli fundust.

Nýleg rannsókn á bráđri kransæðastíflu³ sýndi hærra hlutfall ungra sjúklinga en fram kom í okkar rannsókn, 5,5\% á móti 1,7\%. Aldursmörkin í peirri rannsókn voru hins vegar nokkru hærri og náđu til 45 ára aldurs.

Ekki var tölfræðilega marktækur munur á nýgengi hjartadreps hér á landi milli tímabilanna tveggja, pó svo nýgengið hafi lækkað örlítið úr 14 í 10 á 100.000 á ári. Eins og gögn Hjartaverndar sýna, hefur nýgengið lækkað um 66\% milli tímabilanna 1980-84 og 2000-04 í aldurhópnum 25-74 ára. Pessi próun á hins vegar ekki við um pennan unga aldurshóp. Sé tekið mið af fjölda innlagna á Landspítalann er hlutfall kransæðastíflusjúklinga sem eru 40 ára eða yngri 1,7\% tímabilið 2005-2009 (tafla I). Hlutfallið er talsvert lægra en í mörgum erlendum rannsóknum sem áætla petta hlutfall á bilinu 4-10\% hjá einstaklingum 40 ára og yngri. ${ }^{4,5}$ Í peim samanburði parf að sjálfsögðu að taka tillit til pess hve íslensku sjúklingahóparnir eru litlir.

Fleiri konur greindust á síðara tímabilinu, 15,8\% á móti 6,9\%, en munurinn var pó ekki tölfræðilega marktækur. Ýmsar rannsóknir frá tíunda áratug síðustu aldar sýna hlutfallið 5-10\% $\%^{4,10}$ pótt hærra hlutfall hafi einnig sést. Rannsókn frá 2002 par sem sjúklingar yngri en 45 ára voru skoðaðir, sýndi að konur voru fjórðungur sjúklingahópsins. ${ }^{8}$ Í VALIANT-rannsókninni frá 2008 var hlutfall kvenna í yngsta aldurshópnum $12 \%{ }^{3}$ en $16,3 \%$ í spænskri rannsókn frá 2014. ${ }^{9}$ Í mörgum rannsóknum virðist tilhneiging vera í pá átt að hlutfall kvenna meðal ungra einstaklinga með brátt hjartadrep fari hækkandi.

Vísbendingar um bættan árangur í meðferð og/eða viðbrögðum við bráðri kransæðastíflu má merkja í pessari rannsókn. Pannig varð marktæk lækkun á hlutfalli peirra sem létust á bráðastigi sjúkdómsins, úr 30\% í 8\%. Sýnt hefur verið fram á mikla lækkun í dánartíðni vegna kransæðasjúkdóms á Íslandi í aldurshópnum 2574 á árabilinu 1981 til 2006. ${ }^{7}$ Bætt meðferð skýrir um 25\% af hinni jákvæðu próun en minni styrkur áhættupátta eins og kólesteróls í blóði, blóðprýstings og reykinga vega pó mun pyngra og skýra um 75\% af lækkaðri dánartíðni úr kransæðasjúkdómi.?

Meðal fertugra og yngri eru mikilvægustu áhættupættirnir sem fyrr ${ }^{6}$ reykingar og ættarsaga. Pó hefur dregið marktækt úr hlutfalli reykingamanna og aðrir áhættupættir eins og háprýstingur og hærri líkamspyngdarstuðull vega nú pyngra en áður. Í samræmi við erlendar rannsóknir frá ýmsum tímum ${ }^{5,9,11-16}$ eru reykingar pó enn einkennandi áhættupátttur pessa sjúklingahóps. Forvarnarstarf gegn reykingum heldur pví fullu gildi sínu og meðal annars er mikilvægt að upplýsa ungt fólk um hvernig reykingarnar flýta æðakölkunarferli í kransæðum og stuðla að pví að sjúkdómur sem aðallega herjar á eldra fólk getur skapað lífshættulegar aðstæður í kransæðum fólks á unga aldri. ${ }^{8}$ Meðalgildi S-kólesteróls tímabilið 2005-2009 var marktækt lægra en í sjúklingahópnum 1980-1984. Í tilviljunarúrtaki Hjartaverndar 1978 sem notað var sem viðmið í fyrri rannsókninni var meðalgildi S-kólesteróls hjá 34 ára karlmönnum 6,27 mmól/L. ${ }^{6}$ Síðan hefur meðalgildi S-kólesteróls almennt farið lækkandi meðal Íslendinga. ${ }^{7}$ Kemur pað einnig fram í pessari rannsókn á ungum einstaklingum með brátt hjartadrep og skýrist ekki af af töku statínlyfja pví enginn sjúklinganna í rannsókninni tók statín. Prátt fyrir kólesteróllækkunina hefur nýgengi ekki lækkað eins og búast hefði mátt við og almennt gerðist meðal landsmanna. ${ }^{7}$ Að minnsta kosti tvær skýringar koma til álita; hlutdeild annarra áhættupátta í sjúkdómsframvindunni gæti hafa aukist og/eða að S-kólesteról sé ekki eins mikilvægur áhættupáttur í ungum einstaklingum og peim eldri.

Hlutfallsleg fjölgun sjúklinga með háprýsting úr 7\% í 30\% milli tímabila vekur athygli enda gagnstæð almennri próun meðal Íslendinga á pessu tímabili.7 Í nýlegri rannsókn á ungum einstaklingum með hjartadrep eða hvikula hjartaöng reyndust einnig um $30 \%$ hafa háprýsting. ${ }^{14}$ Aðrar rannsóknir sýna hlutföll á bilinu 1483\%. ${ }^{4}$ Spyrja má hvort breyttar neysluvenjur hjá ungu fólki eigi 
pátt í hærra hlutfalli sjúklinga með háprýsting eða hvort áhrif ofpyngdar komi fram í auknum háprýstingi en karlpátttakendurnir í pessari rannsókn voru marktækt pyngri seinna tímabilið en pað fyrra og 76\% peirra hafði LPS yfir 25. Ofpyngd var hins vegar ekki talin marktækur áhættupáttur tímabilið 1980-1984.

Fjölmargar rannsóknir hafa sýnt tengsl milli ofpyngdar og annarra áhættupátta og ber par hæst blóðfituhækkun, háprýsting og sykursýki. ${ }^{20}$ Nýleg rannsókn sýndi áhrif offitu á æðakölkun gegnum lækkaðan styrk adipónektíns í blóði og aukið magn

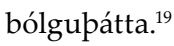

Sykursýki hefur í erlendum rannsóknum komið fram sem marktækur sjálfstæður áhættupáttur kransæðastíflu meðal ungs fólks. ${ }^{9}$ Í pessari rannsókn voru aðeins prír sykursjúkir einstaklingar (einn í fyrri rannsókninni) og pannig of fáir til að unnt sé að meta vægi sjúkdómsins. Pess ber pó að geta að sykursýki er oft vangreindur sjúkdómur. ${ }^{19}$

Fjölmargar rannsóknir hafa sýnt að um helmingur ungra sjúklinga með hjartadrep hefur einnar æðar sjúkdóm. ${ }^{5,12}$ Bæði rannsóknartímabilin var hlutfallið enn hærra hér á landi og um 74\% á seinna tímabilinu. Prengsli í vinstri framveggskvísl (LAD) voru algengust á báðum tímabilum sem er hliðstætt fyrri rannsóknum. ${ }^{12,23}$ Miðað við eldri aldurshópa virðist ungt fólk sem fær brátt hjartadrep pannig nokkuð oft hafa pá sérstöðu að hafa óstöðuga fituskellu og mikla tilhneigingu til segamyndunar pótt ekki sé um útbreiddan sjúkdóm að ræða. Hugsanlega á hin gríðarháa reykingatíðni hlut að máli en reykingar eru pekktar að pví að auka líkur á segamyndun. ${ }^{21}$

\section{Takmarkanir og styrkleikar}

Rannsóknin var afturskyggn og gögn pví misvel skráo. Rannsóknarhópurinn var lítill og tölfræðilegt afl takmarkað enda sjúkdómurinn sjaldgæfur í pessum aldurshópi. Мeð tilkomu trópónínmælinga í blóði milli rannsóknartímabila breyttust greiningarskilmerki. Samanburður milli tímabila varð pví að sumu leyti vandasamari hér á landi sem og annars staðar. Næmi greiningaraðferða hefur aukist með peim afleiðingum að minni hjartadrep greinast og jafnvel almennt vægari sjúkdómur. Samanburður á præðingarniðurstöðum pessara tveggja tímabila rennir einnig stoðum undir að slík próun hafi orðið. Hlutfall sjúklinga á seinna tímabilinu sem annaðhvort höfðu engin marktæk prengsli eða einnar æðar sjúkdóm var marktækt hærra en á fyrra tímabilinu.

Styrkleikar rannsóknarinnar felast í pví að hún nær til allra sjúklinga heillar pjóðar samfellt í 5 ár par sem öll sjúkrahús landsins vísa ungu fólki með kransæðastíflu til Landspítalans til hjartapræðingar og kransæðamyndatöku. Fyrir pennan sjúkdóm er upptökusvæði Landspítalans pannig allt landið. Einnig var fullur aðgangur að heildstæðum klínískum gögnum og áreiðanlegum samanburðarhópum. Í nýlegum erlendum rannsóknum er ríkuleg samsvörun við áhættupættina sem vega pyngst í báðum íslensku rannsóknunum.

\section{Ályktanir}

Brátt hjartadrep í ungu fólki á Íslandi er fyrst og fremst sjúkdómur karlmanna og helstu áhættupættir eru reykingar og ættarsaga. Reykingar og hátt kólesteról eru á undanhaldi en háprýstingur og aukin líkamspyngd fá aukið vægi. Lífslíkur fara batnandi en eins og kom fram á árabilinu 1980-1984 virðast ungir hjartadrepssjúklingar oftast fá kransæðastífluna án pess að æðakölkun sé útbreidd í kransæðum. Nýgengið stendur næstum pví í stað prátt fyrir mikla almenna lækkun í pjóðfélaginu. Skýringarnar eru ekki augljósar og gætu verið margslungnar. Áhrif ævilangra erfðapátta eru erfiðari viðfangs en umhverfispættir. Há tíðni reykinga bendir einnig til lakari stjórnunar á áhættupáttum en almennt tíðkast í pjóðfélaginu.

\section{Pakkir}

Pakkir fá Kristján Óli Jónsson, Matthildur Hjartardóttir, Birna Másdóttir, starfsfólk Skjalasafnsins í Vesturhlíð, starfsfólk Hjartadeildar Landspítala og ritarar deildarinnar. 


\section{Heimildir}

1. Laslett LJ, Alagona P, Jr., Clark BA, 3rd, Drozda JP, Jr., Saldivar F, Wilson SR, et al. The worldwide environment of cardiovascular disease: prevalence, diagnosis, therapy, and policy issues: a report from the American College of Cardiology. J Am Coll Cardiol 2012; 60: S1-49.

2. Gudbjartsson $T$, Andersen $K$, Danielsen $R$, Geirsson $A$ Thorgeirsson G. Yfirlit um kransæðasjúkdóm - fyrri hluti: Faraldsfræði, meingerð, einkenni og rannsóknir til greiningar. Læknablaðið 2014; 100: 667-76.

3. Anderson RE, Pfeffer MA, Thune JJ, McMurray JJ, Califf $\mathrm{RM}$, Velazquez E, et al. High-risk myocardial infarction in the young: The VALsartan In Acute myocardial iNfarcTion (VALIANT) trial. Am Heart J 2008; 155: 706-11.

4. Choudhury L, Marsh JD. Myocardial infarction in young patients. Am J Med 1999; 107: 254-61.

5. Zimmerman FH, Cameron A, Fisher LD, Ng G. Myocardial-Infarction in Young-Adults - Angiographic characterization, risk-factors and prognosis (CoronaryArtery Surgery Study Registry). J Am Coll Cardiol 1995; 26: 654-61.

6. Sigurðsson A, porgeirsson G, porgeirsson G. Brátt hjartadrep á Íslandi árin 1980-1984 í einstaklingum 40 ára og yngri. Læknablaðið 1988; 74: 167-76.

7. Aspelund T, Gudnason V, Magnusdottir BT, Andersen $\mathrm{K}$, Sigurdsson G, Thorsson B, et al. Analysing the large decline in coronary heart disease mortality in the Icelandic population aged 25-74 between the years 1981 and 2006 . Plos One 2010; 5: e13957.
8. Doughty M, Mehta R, Bruckman D, Das S, Karavite D, Tsai $\mathrm{T}$, et al. Acute myocardial infarction in the young The University of Michigan experience. Am Heart J 2002; 143: 56-62.

9. Esteban MR, Montero SM, Sanchez JJ, Hernandez HP, Perez JJ, Afonso JH, et al. Acute coronary syndrome in the young: clinical characteristics, risk factors and prognosis. The Open Cardiovasc Med J 2014; 8: 61-7.

10. Teng JK, Lin LJ, Tsai LM, Kwan CM, Chen JH. Acute myocardial-infarction in young and very old chinese adults - Clinical characteristics and therapeutic implications. Int J Cardiol 1994; 44: 9-36.

11. Panagiotakos DB, Rallidis LS, Pitsavos C, Stefanadis C, Kremastinos D. Cigarette smoking and myocardial infarction in young men and women: A case-control study. Int J Cardiol 2007; 116: 371-5.

12. Chen LJ, Chester M, Kaski JC. Clinical factors and angiographic features associated with premature coronary-artery disease. Chest 1995; 108: 364-9.

13. Hoit BD, Gilpin EA, Henning H, Maisel AA, Dittrich H, Carlisle J, et al. Myocardialinfarction in young-patients an analysis by age subsets. Circulation 1986;7 4: 712-21.

14. Teixeira M, Sa I, Mendes JS, Martins L. Acute coronary syndrome in young adults. Rev Port Cardiol 2010; 29: 94755.

15. Mannfjöldatölur Hagstofu Íslands, 2005-2009.

16. Jamil G, Jamil M, Alkhazraji $H$, Haque A, Chedid F, Balasubramanian $\mathrm{M}$, et al. Risk factor assessment of young patients with acute myocardial infarction. Am J Cardiovasc Dis 2013;3:170-4
17. Bhardwaj R, Kandoria A, Sharma R. Myocardial infarction in young adults-risk factors and pattern of coronary artery involvement. Nig Med J 2014; 55: 44-7.

18. Wilson PWF, D'Agostino RB, Sullivan L, Parise $\mathrm{H}$, Kannel WB. Overweight and obesity as determinants of cardiovascular risk - The Framingham experience. Arch Int Med 2002; 162: 1867-72

19. Bergsveinsson J, Aspelund T, Guðnason V, Benediktsson R. Algengi sykursyki af tegund tvo a Islandi 1967-2002. Læknablaðið 2007; 93: 397-402.

20. Murray ET, Hardy R, Hughes A, Wills A, Sattar N, Deanfield J, et al. Overweight across the life course and adipokines, inflammatory and endothelial markers at age 60-64 years: Evidence from the 1946 birth cohort. Int J Obes 2015; 39: 1010-8.

21. Ambrose JA, Barua RS. The pathophysiology of cigarette smoking and cardiovascular disease: an update. J Am Coll Cardiol 2004; 43: 1731-7.

22. Barua RS, Ambrose JA. Mechanisms of coronary thrombosis in cigarette smoke exposure. ATVB 2013; 33: $1460-7$.

23. al-Koubaisy OK, Mehdi RS, Arem FD, Ahmed IT. Cine angiographic findings in young Iraqi men with first acute myocardial infarction. Cathet Cardiovasc Diagn 1990; 19 $87-90$.

\section{ENGLISH SUMMARY}

\section{Acute myocardial infarction among Icelanders forty years old and younger 2005-2009.}

\section{Comparison with a study carried out 1980-1984}

Björn Jakob Magnússon¹, Uggi Agnarsson², Pórarinn Guðnason², Guðmundur Porgeirsson,2

Introduction: While acute myocardial infarction (AMI) mostly is a disease of the elderly it also affects younger individuals, often with serious consequenses. In 1980-1984 a study was carried out on the incidence, risk factors, infarct location and distribution of atherosclerosis among Icelanders forty years and younger with AMI. Here we present the results of a similar study carried out for the five year period 2005-2009. Materials and methods: Medical and autopsy records of all individuals, forty years and younger, diagnosed with AMI (I21 in ICD-10) at Landspitali, National University Hospital 2005-2009, or suffering sudden cardiac death in Iceland during the same period were reviewed. Blood tests, electrocardiograms, echocardiograms, coronary angiograms and autopsy results were reviewed with respect to AMI-criteria. Statistical comparisons of ratios and means were carried out using Chi-square test and T-test, respectively.

Results: 38 individuals 40 years and younger, 32 males and 6 females, fulfilled the diagnostic criteria of AMI. Calculated incidence for the population at risk was 10/100.000/year (14/100.000/year in 1980$1984)$ and the mean age \pm S.D. was $36.7 \pm 3.9$. Three $(7.9 \%)$ died suddenly before reaching hospital but of the 35 hospitalised patients 30 day mortality was zero, compared to nine $(23.7 \%)$ pre-hospital deaths and two (6.9\%) hospital deaths in 1980-1984. Thus, combined pre-hospital and in-hospital (30 day) mortality was $28.9 \%$ and $7.9 \%$ in the previous and recent time periods, respectively ( $p=0.02)$. In 2005-2009, $77.1 \%$ had a smoking history and $31.4 \%$ were hypertensive compared to $97 \%$ and $6.9 \%$ in $1980-85$ ( $p=0.026$ and $p=0.015$, respectively). Body mass index (BMI) was higher in the later period, $28.6 \pm 4,8 \mathrm{~kg} / \mathrm{m}^{2}$ compared to $26.1 \pm 3.6$ (mean \pm S.D.; $p=0.04$ ) but $\mathrm{s}$-cholesterol was lower, $5.1 \pm 1.4$ $\mathrm{mmol} / \mathrm{L}$ compared to $6.3 \pm 1.16$ ( mean \pm S.D.; $\mathrm{p}<0.01$ ). In both studies single coronary artery disease was the most common angiographic pattern and the left anterior descending artery most often involved. Conclusion: Our results show that in two surveys 25 years apart AMI patients 40 years and younger are most often men. Smoking and family history were the most prominent risk factors during both periods but hypertension and high BMI were more common in 2005-2009 than in 1980-1984. Prognosis, as indicated by combined pre-hospital and in-hospital (30 day) mortality has improved.

${ }^{1}$ Faculty of Medicine University of Iceland, ${ }^{2}$ National University Hospital, Reykjavik, Iceland.

Key words: Myocardial infarction, forty and younger, incidence, risk factors, mortality, time trend

Correspondence: Guðrmundur Porgeirsson gudmth@landspitali.is 